\title{
Partial Horizontal Differentiation in Croatian Higher Education: How Ideas, Institutions and Interests Shape the Policy Process ${ }^{1}$
}

\author{
Jelena Brankovic \& Martina Vukasovic
}

Centre for Higher Education Governance Ghent, Ghent University, Ghent, Belgium

\footnotetext{
${ }^{1}$ The chapter has been published in H. de Boer, J. Huisman, J. File, M. Seeber, M. Vukasovic, \& D. F. Westerheijden (Eds.), Policy Analysis of Structural Reforms in Higher Education: Processes and Outcomes (pp. 53-73). Springer International Publishing. DOI 10.1007/978-3319-42237-4_3
} 


\section{Introduction}

After the dissolution of the former Yugoslavia in the early 1990s, Croatia embarked on a number of public sector reforms, higher education included. Since then, higher education legislation changed several times, introducing, amongst other, a new degree structure and a system of quality assurance and accreditation. The main structural reform in Croatia, today spanning more than two decades, aimed to increase horizontal differentiation among higher education institutions, which meant the re-introduction and strengthening of non-university higher education provision. Importantly, this reform has always been embedded in more general ones. During the 1990s, strengthening the non-university higher education was part of the broader agenda of achieving a balanced regional economic development in the newly independent Croatia, while in the 2000s it was part of implementing the Bologna Process action lines and the overall process of EU accession.

Increasing horizontal differentiation among higher education institutions in Croatia in practice implied two systemic changes. The first one concerned the establishment of non-university higher education institutions, in particular outside the cities such as Zagreb, Split and Rijeka traditionally the seats of the largest universities in the country. The second change was the gradual abolishment of professional programmes at universities. And while the first change has to some extent been made, the abolishment of professional programmes at universities remains on the policy agenda to date, suggesting that the reform goals have been, at best, only partially achieved.

In this chapter we take a closer look at these developments and offer an account of how and why strengthening horizontal differentiation in Croatian higher education persists as a challenge for policy makers. We start with presenting the conceptual framework we use for analysing policy success and failure. The central part of the chapter consist of both analysis and discussion on the extent to which reform goals have been achieved, whether this constitutes policy failure and how specific characteristics of the reform, such as the policy content, institutional arrangements, on one hand, and politics of this reform, on the other, are related to such reform outcome. In the concluding section, the main features of the reform design, implementation, monitoring and evaluation are summarized and implications for policy-making and policy analysis discussed. 


\section{Assessing and explaining policy outcomes: a conceptual}

\section{framework}

There is a general agreement among policy scholars that policy successes and policy failures are both political and normative and are therefore, at best, 'contested constructs' (Bovens and 't Hart 2016). Whether something is labelled a failure or a success is part of a discursive practice deployed by policy makers and practitioners, rather than related to inherent attributes of policy implementation in question (Bovens and 't Hart 2016, Zittoun 2015). As each public policy is normally accompanied both by its advocates and critics, it is these groups who are expected to be primarily engaged in such discursive practices (Bovens and 't Hart 2016). Moreover, given that each policy is expected to benefit some more than others, different actors and interest groups involved would engage differently in such practices. The verdict, by extension, may be a result of a power game of sorts, rather than of an objective, evidence-informed analysis, provided such is even possible. This, however, does not mean that failures or successes do not exist per se, but that such judgements are both political and normative (Bovens and 't Hart 2016). The political nature of such judgements means taking into account that they may have consequences both for future developments and for the actors involved. Being normative, on the other hand, means that an assessment of success or failure is often based on implicit criteria that tend to be ideological or that the criteria chosen by specific actors to proclaim success or failure may be subject to debate.

Given these challenges, one approach would be to judge the success of the reform in relation to the goals proclaimed by the creator of the reform which is - in this as in other similar reforms in higher education - the state. Here one needs to make a distinction between instrumental goals - what kind of changes are planned for the higher education system, and strategic goals - what wider impact will these changes have on the overall functioning of the system and its relationship with other parts of the public sector. For example, in the case of the Croatian reforms, the instrumental goals were to introduce and strengthen the non-university provision and to abolish professional programmes in universities. The strategic goals included increasing quality and efficiency of higher education, boosting regional development and increasing the educational attainment of the population. Judged in this way, and taking into consideration the current state of affairs, the Croatian two-decade long effort to introduce and expand the nonuniversity sector and to abolish professional programmes at universities seems to be closer to a case of failure than a success (see below for a detailed elaboration). 
However, this assessment needs to be unpacked in two ways: (1) what is the nature of the reform outcome, i.e. what is it that actually failed and (2) why did such an outcome emerge?

Here, and based on our assessment of the case as 'closer to failure than success', we follow Peters (2015) who argues that there are different kinds of policy failures, depending on their characteristics, but also their sources. He therefore distinguishes among four types of failures: state failure, governance I and II failures, and policy failure. State failure refers to state's incapacity of providing basic services, such as public order and the rule of law. This applies to the so-called 'failed states'. A somewhat less dramatic type of failure is governance I failure which refers to 'the incapacity to provide systematic direction to the society and economy' (Peters, 2015, p. 263). Governance II failures, on the other hand, are those in which governments fail to deliver policies addressing specific policy domains and their issues. Finally, policy failure, according to Peters, is primarily a failure to reach specific policy goals.

Importantly, while policy failure may occur independently of the other three types, it should not be treated in isolation. Contrary to what may be inferred from most of the literature on failures, Peters (2015) argues that the political or socio-economic environment within which policies are being made are more often the reason why a certain policy fails than the policy itself. Taking a closer look at the contextual factors related to the state structure or governance arrangements may lead us to some important insights on conditions under which policies are more or less likely to succeed or fail. This approach is especially valuable in situations in which failure to achieve (fully) the stated policy goals may be due to both problems with the policy itself, as well as with the overall governance arrangements (i.e. governance II failure), which is what we claim was the situation in Croatia. Therefore, in addressing the 'why' of specific reform outcomes, we analyse both the policy itself (its design and implementation), as well as the systemic conditions in relation to institutional arrangements and actor constellations and interests which may have impeded its implementation.

We argue that the conditions under which policies are developed and implemented are particularly important. In the case of Croatia this pertained to the outcomes being preceded by a 'bumpy' implementation road. The importance of context in analysing and explaining policy outcomes has also been stressed by May (2015). He argues that the governing arrangements for addressing policy problems are undergirded by the interplay among (a) ideas (policy content), (b) institutional arrangements (structures of authority, attention, information, and organizational relationships) and (c) interests (constituencies that provide interest support and opposition). In addition to policy content, institutional arrangements and interests, May (2015) 
also stresses the importance of the temporal dimension inherent to any policy process. As Majone and Wildavsky (1984) claim, policies constantly evolve, much like the context in which they are embedded together with its defining aspects, such as governance arrangements, actors and their interests, and resource dependencies. We use this approach to elaborate our analytical framework and we take each of the three elements in turn.

Ideas and policy content. With respect to ideas, we see them as the very essence of policies, also referred to as the policy content (Gornitzka 1999). Policy content can be seen to comprise a statement of policy problems and objectives identified, linkages of the policy under analysis with other policies that are relevant in the field and policy instruments (Gornitzka 1999). ${ }^{2}$ Concerning policy problems and objectives, some policies may be rather ambiguous in one or both of these aspects. Moreover, even in cases in which both problems and objectives are stated rather explicitly, the proposed solutions may not be adequate to address the stated problems. This is in particular the case in situations of significant ambiguity and complexity, when it is not possible to identify and assess the different policy options (as suggested by Kingdon 2003 in relation to the so-called multiple streams framework for policy analysis).

Policy linkages refer to the extent a reform is compatible with other policies relevant for the sector. These include horizontal linkages, i.e. policies concerning related policy issues or related policy sectors (e.g. secondary education or research), vertical linkages with policies promulgated by other governance levels (local authorities, federal governments etc.), as well as historical linkages, i.e. the extent to which the specific reform reflects institutionalized policy legacies. Given that change in higher education is slow and incremental (Musselin 2005), strong policy linkages are linked to less problems in implementation. In the Croatian context, given that other governance levels do not have significant competences with regards to higher education policy, horizontal and historical policy linkages are particularly important.

Concerning policy instruments and their potential impact on the 'why' of policy outcomes, it is necessary to first explore whether the developed policy instruments correspond to the proclaimed policy goals and whether different instruments are compatible with each other (e.g. are changes in regulation supported or undermined by the funding mechanism). Moreover, it is important to assess whether the developed policy instruments reflect the specific institutional

\footnotetext{
2 Gornitzka also states the "normative basis", i.e. the underlying ideology, as an element of policy content. However, due to the fact that the analysed policy documents do not include explicit references to ideological principles, this aspect of the policy content of the Croatian structural reform will not be analysed in this chapter.
} 
arrangements and the interests of specific actors. In situations in which this is not the case - e.g. policy instruments developed implying that some of the main actors in the policy arena would effectively lose if the reform is fully implemented - it is likely that the implementation will not be without problems and that the reform goals may not be achieved.

Institutional arrangements concern the organization of the policy process in general and overarching governance characteristics. Analyses of institutional arrangements focus on the relationship between the state, the organizations in the sector (in this case higher education institutions) and the relevant stakeholders (e.g. students, trade unions, employers, etc.). Thus, a distinction can be made with regards to the extent to which different stakeholders take part in design, implementation and evaluation of the policy process.

The state steering approach is an important element of the broader institutional arrangements (Gornitzka and Maassen 2000; Olsen 1988). There are cases in which the state is dominant and in which consultation with the actors is quite limited, leading to policies that predominantly reflect state interests and in which the state has significant control over the implementation and evaluation process (what Gornitzka and Maassen refer to as sovereign state model). There are also cases in which stakeholders play a significant role (corporate-pluralists steering), requiring bargaining and negotiation between stakeholders with diverse interests, potentially leading to ambiguous policy goals and incompatible policy instruments, which in turn means a less than smooth implementation process and contestation over the success of the reform (Gornitzka and Maassen 2000). The state can also grant significant autonomy to the institutions expecting them to compete in the market for students, staff, funding etc. (supermarket steering model), leading to light touch regulation and competitive funding mechanisms with very limited (if at all) public funding. Control over the implementation in this case is left in the hands of the institutions and the success of the reform is then linked to the success of institutions surviving in the market. Finally, the bulk of the control can also be in the hands of the academic profession (institutional steering model), meaning that change happens 'through historical process and evolution rather than as a result of the reform' (Gornitzka and Maassen 2000, p. 271).

Steering in a particular higher education system is likely to be a mixture of the four steering models presented above, with historical legacies determining which approach is more dominant than others (Gornitzka and Maassen 2000). These historical legacies also concern the reliance on specific policy instruments and the use of information. In some systems, reforms may predominantly rely on regulation, while others may focus on funding incentives. In some systems, there may be a long tradition of using information about higher education systems 
performance to inform future policy decisions, thus leading to a more rationalist approach to decision-making (see "Structural Reform in European Higher Education: An Introduction"). In other cases, information may be used opportunistically by different actors in the arena to justify their specific preferences or it may not be used at all, in both cases implying that the main determinant of specific policy decisions are pre-existing policy preferences of (most dominant) actors in the arena and not necessarily the characteristics and performance of the system as such.

Actors and their interests. Actors and their interests are what we refer to when we speak of politics of the policy process. While actors may vary with regards to their power and authority, as well as their role in policy implementation, Peters (2015) suggests that when we speak of failures to implement certain policy, we need to take into account that actors can also act as veto players and that a governance system may have multiple veto points. Referring to George Tsebelis, he suggests that 'everything else being equal, a governance system is more likely to fail the greater the number of independent veto points and veto players there are in that system' (Peters, 2015, p. 268). Stalemate or incapacity to make important decisions are, he argues, typical of governance failures due to veto players.

However, Tsebelis (2002) focuses primarily on actors who are veto players due to their formal position in the policy arena and policy-making process, e.g. those who have a formal and explicit power to veto a decision (e.g. a president can veto a law). However, given that this neglects the informal aspects of governance and the fact that policy actors can wield power even when not formally in the position to do so (Sørensen and Torfing 2003), we focus also on actors who may be effectively veto players due to their influence over actors who are formally veto players. For example, if a buffer structure is formally a veto player but at the same time dominated by representatives of a profession, then effectively the said profession is a veto player as well. In other words, we go beyond the formal descriptions of actors and do not assume that all actors are independent from each other.

In sum, our analysis of the Croatian structural reform will focus on the following:

1. What is the policy outcome, i.e. can it be assessed as failure and, if so, what kind of failure? 
2. Why did this policy outcome happen, i.e. what is the relationship between the policy content, institutional arrangements and actors' interests on the one hand, and the specific policy outcome, on the other?

The following section will first provide a brief chronology of the structural reform in Croatia and will then address the 'what' and the 'why' questions.

\section{Unpacking policy process: the 'what' and 'why' of Croatian partial horizontal differentiation}

\section{The chronology of the reform}

Until the early 1990s, Croatia was part of the Socialist Federal Republic of Yugoslavia (SFRY). The most important legacy from this time concerns the sweeping reform of the entire education system initiated in the 1970s, streamlining the secondary and higher education systems strongly to the needs of the labour market (Bacevic 2014). One consequence of this was that although predecessors of non-university higher education institutions existed in Croatia since WWII, they were (a) not considered part of the higher education system, but rather as post-secondary education and (b) almost completely dissolved in the late 1980s, either by being amalgamated into universities (or rather their constituent faculties) or by disappearing altogether (Reichard 1992). The other consequence was that the period immediately before the 1990s was marked by the growing dissatisfaction with effects of this reform and therefore the main aim with the first higher education legislation in independent Croatia, adopted in 1993, was to 'do away' with this 'legacy'. This law introduced the distinction between (a) universities and (b) nonuniversity HEIs, as well as the distinction between (1) academic studies and (2) professional studies. Universities could provide both types of studies, while non-university institutions could provide only professional studies. The legislation also stipulated that the professional studies at universities should be abolished by the 1999/2000 academic year.

In 1995, the Croatian Parliament changed the legislation and prolonged the deadline for abolishment of professional programmes in universities to 2002/2003. Further attempts to abolish professional studies at universities were prevented by the 2000 Decision of the Croatian Constitutional Court (hereinafter: Court). Namely, upon an official complaint made by some of the universities that several provisions of the law were essentially violating the principle of autonomy guaranteed by the Croatian constitution, the Court decided that limiting universities 
to organizing only certain types of studies was unconstitutional, effectively eliminating the articles which required that universities abolish professional programmes.

When Croatia joined the Bologna Process in 2001, the new legislation, supporting a root-andbranch reform of the whole system, was adopted in 2003. Strengthening the horizontal differentiation was also on the agenda, with a clear instrumental goal to remove vocational content from university studies, in order to allow universities to focus more on research and to ensure that the non-university sector could develop. The legislation clearly stated that universities were expected to provide academic study programmes (three cycles) and nonuniversity institutions vocational ones (two cycles). At that time possibilities for vertical mobility between the two types were asymmetrical; enrolling into the second professional cycle was possible with either a professional or an academic first cycle degree, while enrolling into the academic second cycle programme was possible only if the first degree was also from an academic study programme. The law stipulated that universities could organize professional study programmes only if they obtained a permit of the National Council for Higher Education (NCHE) and that they are allowed to enrol students into such programmes only until 2010/2011. This plan to abolish professional studies in universities was once again disrupted by the Court, which in 2006, upon another complaint from the universities, ruled that such legislative provisions were unconstitutional (citing also the decision from 2000 as legitimation).

In 2009, a special law dealing only with quality assurance in higher education research was adopted. The key provision concerned the freedom of universities to develop their own study programmes and not be subjected to programme accreditation, as stipulated by the 2003 legislation, while non-university institutions were expected to undergo re-accreditation of their study programmes every five years.

Meanwhile, the government's intention to achieve a clear binary divide and abolish the practice of universities organizing professional studies continued to be present in overarching strategic documents, linking this structural reform with the overall reform of higher education and relating its instrumental goals with strategic goals of developing Croatia as a knowledge-based society, improving the overall educational attainment of the working population, increasing efficiency and equity of higher education and ensuring a more balanced regional development. In an attempt to improve quality and accessibility of higher education, as well as to ensure relevance of study programmes for both local and national strategic needs, the Parliament adopted the document 'Network of higher education institutions and study programmes in 
Croatia' in 2011. The document was to guide decisions on programme accreditation and, by extension, on spending of public funding for higher education, given that student numbers in each accredited programme in a public institution were automatically taken into account in input-based funding allocations. When deciding whether universities should be given special permission for professional study programmes, the NCHE was to base its decisions on fifteen elaborate criteria concerning, e.g. existing offer of study programmes and specific regional needs.

Finally, in 2013, the Parliament adopted the legislation on the Croatian qualifications framework, clarifying its linkages with European Qualifications Framework and Qualification Framework for the European Higher Education Area. The legislation put academic and professional degrees from the same cycle on an equal level (e.g. both professional and academic second cycle degrees correspond to EQF level 7), but the asymmetry with regards to mobility between university and non-university programmes was maintained; transfer from the former to the latter was possible, but not the other way around.

\section{The 'what' of policy outcome: Have the reform goals been achieved?}

The fact that there were almost no non-university higher education institutions in the 1990s and now there are 38 may be interpreted as achievement of at least one operational goal of the reform - the introduction of the non-university sector. Most of the currently operating nonuniversity institutions were established in the second half of the 2000s, with the number doubling between 2005 and 2011. The number of students in professional programmes organized by universities has decreased in recent years. According to the Croatian Bureau of Statistics, the number of students in professional programmes at universities decreased from approximately 22,000 in $2004 / 2005$ to just over 17,000 in $2013 / 2014$. However, they still constitute only one-third of all students in professional programmes, suggesting that the operational goal to phase-out professional programmes in universities - by allowing them only as an exception given special permission by NCHE - has yet to be achieved. Effectively, this means that operational goals have only been partially achieved.

Concerning the strategic goals, while the bulk of the higher education provision is still concentrated in the capital city, each administrative region now has at least one institution, which was not the case in the early 2000s. Keeping in mind that the non-university sector actually caters to students of lower socio-economic background (Cvitan et al. 2011), one would expect that expanded provision outside of the capital region could potentially improve access 
overall. However, the expansion of provision is in some cases rather narrow, including only one institution with a limited offer of study programmes (in 1-2 areas), primarily in social sciences (economics) and nursing. Moreover, the tuition fees in non-university institutions, particularly private institutions, are higher than in universities (Cvitan et al. 2011, Doolan, Dolenec, and Domazet 2011), which means that under the current funding arrangements nonuniversity programmes may actually be less accessible to students from lower socio-economic backgrounds. Similarly, although the educational attainment of the population seems to have improved - from $12 \%$ of the population with a higher education degree in 2001 to now about a quarter of the population with at least first cycle degree - it is difficult to make a clear causal link with the structural reforms, given that the effects of demographic changes have not been systematically studied and that it is not clear how the introduction of the 'Bologna' $3+2$ degree structure affected the education attainment.

In sum, although there has been a clear increase in the number of non-university institutions and the professional study programmes they offer, in particular from 2005 onwards, continuous resistance to clarifying horizontal differentiation by allowing only non-university institutions to provide professional study programmes and an unclear situation with regards to strategic goal implies that the structural reform in Croatia has been overall partially successful at best.

\section{The 'why' of the policy outcome}

\section{Policy content}

For the better part of the 1990s, the proposed solution, i.e. the instrumental goal of the reform to establish and strengthen the non-university sector in Croatia was not explicitly linked to specific policy problems, i.e. the reform's strategic goals. This is to some extent caused by the fact that the structural reform was never a 'stand-alone' reform but always a smaller element in much larger reform projects that concerned the main part of the higher education system - the universities. This embeddedness of the structural reform in the larger reform project may, at first glance, indicate that the horizontal linkages between the reform and other policies related to higher education were particularly strong. However, an analysis of policy documents, in particular from the mid-2000s onwards, suggests that the structural reform was actually of secondary importance, compared to the reform of universities. The ideas about and challenges for the non-university higher education were discussed to a much lesser extent, while the reform of universities, including their governance and degree structure of the programmes they offered 
took the lion share of attention. Moreover, the structural changes that the reforms were envisaging did not have strong historical linkages with the previous higher education policy. The reform was envisaging the establishment of a whole new sector and, perhaps most importantly, the institutionalized practice that the universities also provide professional programmes was supposed to be abolished, indicating that the expected change was far from incremental.

Overall, insufficient attention was given to the development of policy instruments, given that (a) the bulk of the reform relied only on changes in legislation and (b) most of these changes actually concerned the overarching reform process and the functioning of the universities and less so the functioning of the non-university sector. The fact that the funding mechanisms were not changed meant that there was incompatibility between policy instruments. The number of students enrolled remained the key criterion for public funding meant that professional programmes were actually an important source of income for the universities, thus undermining the regulation which foresaw that these programmes should be abolished. Therefore, it may not be at all surprising that the legislation was effectively re-designed during implementation, by the Parliament as well as by the Constitutional Court. This iterative characteristic of the policy process in which design and implementation overlap implies that it is necessary to consider the whole of the policy process and not assume that specific stages are clear-cut and isolated processes. Moreover, the back-and-forth of the reform is also a consequence of institutional arrangements and politics of the Croatian structural reform.

\section{Institutional arrangements}

Currently (and throughout the reform period), the steering model in place in Croatia can be categorized as predominantly institutional, with elements of the market model introduced over the past two decades. ${ }^{3}$ This means that the bulk of the control in the sector is effectively in the hands of the academic profession and, by extension, the specific organizational actors that the academic profession dominates. These are first and foremost the universities but also the NCHE, given that the majority of its members is nominated by the universities.

Having such a steering approach has a number of implications. First, it means that the policies reflect the interest of the academic profession. The first aspect refers to the structural reform process being a minor part of the larger reform that dealt with universities. Not only was this

\footnotetext{
${ }^{3}$ Prior to dissolution of Yugoslavia (1992), it was predominantly the state control model.
} 
visible in the fact that less attention was given to the structural reforms in the strategic documents, but also in how regulation was developed. The key legislative provisions related to abolishing professional study programmes in universities were part of the so-called 'concluding and transitional provisions' in the legislation which are usually not subject to significant consultations prior to Parliamentary adoption, but may be amended afterwards in case it becomes evident that their implementation will go against the interests of specific actors. This is precisely what took place in Croatia - these provisions were once amended by the Parliament (in the 1990s) and twice proclaimed unconstitutional by the Court (in the 2000s).

The dominance of the academic profession in the Croatian policy arena, as well as the historical legacies from the former Yugoslavia, together led to the situation in which policy development primarily relied on legislation and other forms of regulation, while not considering significant changes of the funding instruments, despite the fact that actors consider funding as the more important policy instrument (according to the interviews).

The information basis of the reform, both in the design phase, and in the monitoring and evaluation has not been particularly strong. Actually, the information basis in the 1990s has been particularly weak given that the analytical capacity of the NCHE and the ministry was rather limited (Orosz 2008). The establishment of the Agency for Science and Higher Education in the early 2000s (ASHE), the increasing prominence of policy analysts within higher education institutions or within independent think tanks (Zgaga 2013), and the existence of many externally (EU) funded projects focusing on analysis of higher education was expected to improve the situation. However, data collected through research projects, often funded by the EU, are used primarily for the identification of policy problems (if at all), and not explicitly as policy evaluation tools. ${ }^{4}$ Moreover, sometimes there are inconsistencies with regards to information. For example, data on student numbers reported by ASHE (citing the Ministry of Science, Education and Sports as the source) and data on student numbers reported by the Croatian Bureau of Statistics (CBS) do not match. Namely, the total number of students

\footnotetext{
${ }^{4}$ An example of this is a large scale project ACCESS (funded through the TEMPUS project), which focused on funding of higher education and socio-economic characteristics of the student population (the latter effectively being the national report for Croatia within the EUROSTUDENT project). Results of the project (Cvitan et al. 2011, Doolan, Dolenec, and Domazet 2011) do highlight problems of reproduction of social inequality in higher education - students of lower socio-economic background are under-represented in universities and underrepresented in higher education in general - but they provide a snapshot of the situation and not a longitudinal analysis potentially useful for evaluating the effects of reforms.
} 
(including postgraduate students) reported by the two sources for the 2013/2014 academic year differs by more than 12,000: 166,061 (CBS) compared to 178,676 (ASHE).

Finally, policy evaluation is, generally speaking, not a systematically organized activity in Croatia. Overall, the collective actors - NCHE, Rectors' Conference, Council of Polytechnics and Schools of Professional HE, and ASHE do publish their annual reports, but these do not have a clear role in the policy design process. In addition, although ASHE does develop thematic reports on external evaluations of institutions and study programmes there does not seem to be an institutionalized way of using these reports. What the data collected by ASHE is used for is to indicate the persistence of problems which earlier reforms were expected to address - very high (and continuously increasing) number of study programmes and the provision of professional programmes by universities.

\section{The politics of the process}

Overall, given the dominance of the academic profession, the possibilities for weaker actors to take part and influence the process are rather limited. This brings forward the question of which actors actually take part and what interests they protect.

Although introducing the binary divide in Croatian higher education was never high on the state's higher education agenda, the state was continuously involved in the implementation process through its branches. The most active branch was certainly the executive one - the ministry responsible for higher education and ASHE. These two bodies have always been the main ones to oversee the implementation of the policy. Taking into account that the policy itself implied changes in legislation, the state's legislative branch - the Parliament was also involved, although not continuously. Finally, the state also acted through its judicial branch, namely, the Court, at two instances (in 2000 and 2006).

Given that the introduction of the binary divide would have affected universities and former post-secondary schools differently, these two types of higher education institutions positioned themselves differently with regards to this policy. They acted both as individual organisations and through their respective councils, the Rectors' Conference in the case of universities and the Council of Polytechnics and Professional Schools of Higher Education. In addition to these two bodies, the two types of higher education institutions are also represented in the NCHE, albeit this body has more university representatives than those representing non-university institutions. 
Described this way, who the main actors are seems to be rather straightforward: the state, universities and non-university institutions. However, the reality is somewhat more complex, given that universities, even without a formal role in the legislative, executive or judicial governing branches, wield significant power over these structures and, therefore, over the policy process. We could, then, conceive of e.g. the Parliament and the Court as penetrated structures (Bleiklie, Enders, and Lepori 2015) whose individual members are either themselves members of the academic community (i.e. university professors more often than non-university academic staff) or under the direct influence of academics. For instance, the Court judges are often either closely linked to the Faculty of Law of the University of Zagreb or academic staff members at some of the law faculties in the country, while the University of Zagreb itself, being the flagship university and the alma mater of the majority of Croatia's political elite, is certainly the most influential higher education institution in the country. Another example is the work of the NCHE. According to the interviewed experts, even though NCHE is expected to allow universities to have professional programmes only under extraordinary circumstances (in line with the 'Network of higher education institutions and study programmes in Croatia'), in practice all applications for such programmes coming from universities are accepted.

Finally, apart from these permanent structures, there are also temporary ones which are convened for specific purposes, such as the development of initial legislative proposals and strategic documents. University professors are particularly active in this phase, given that universities are considered both a major stakeholder, but also an authority on various issues. One example of this is the most recent Strategy for Education, Science and Technology adopted by the Parliament in 2014. The development of the strategy was steered by the academic community, and the vast majority of individuals involved were university professors; no one from non-university HEIs was involved in the team focusing on higher education reforms in general, while the sub-team focusing on the binary characteristics of the higher education system consisted of three university and two non-university professors.

In addition to being active in the design phase of the policy process, universities are also active in the implementation phase. They do this by pushing for legislative amendments in the Croatian Parliament or, as already suggested, by submitting complaints to the Constitutional Court concerning specific legislative provisions.

On the other hand, non-university HEIs are relatively weaker as actors, although their influence over the policy process and their relative power has increased over time. Their position is certainly affected by their characteristics, relative to universities. They are comparably smaller, 
younger (most of them established in the second half of the 2000s) and less comprehensive. They are also more heterogeneous, which may mean that they have more diverse interests. If this is indeed the case, this would be another factor impeding stronger cohesion among them and reducing their capacity to act as one. At the same time, they are, as elsewhere, often considered to be of lower quality and tend to enjoy lower status (especially given that almost all private institutions are non-university institutions). All these factors affect their relative authority on higher education policy matters and, consequently, their legitimacy as a policy actor.

With regards to the actors' respective interests, one thing that is clear is that throughout the period universities sought to maintain the advantageous position they enjoyed, for which purpose they used their influence across different structures and at all stages of the policy process. In specific, they were reluctant to give up their right to provide professional study programmes, given that this was seen as reducing state funding. They were also keen to protect the relative standing of their own study programmes, in terms of access to further education, which they saw as being threatened by competition from the polytechnics and professional schools. Non-university higher education institutions, on the other hand, were and still are, relatively weaker to push for a better position in the system.

At the same time, the ability of the state to secure a more successful policy implementation was hampered by at least three factors. First, this particular policy has never been high enough on its agenda to challenge the position of universities. Second, as already indicated, some of its structures have been penetrated and therefore under direct influence of universities, which would have probably diluted the influence of the state even if the policy had been on top of its agenda. Finally, as suggested earlier, the authority of the state in academic matters is lower when compared to that of universities. Thus, given that a functioning binary system does not enjoy legitimacy in the eyes of universities, it is hardly surprising that universities seek to obstruct its implementation by all legitimate means at their disposal.

When placed next to other actors, universities are, effectively, a veto player and a very powerful one. Presence of veto players is, as earlier suggested, yet another predictor of a policy failure, although as such it represents a failure of the governance structure, rather than the policy itself. 


\section{Conclusion}

This chapter described and analysed the developments related to the non-university sector in Croatia since the mid-1990s. These developments included the establishment of a number of non-university higher education institutions which provide professional programmes, and attempts to gradually abolish provision of such programmes in universities with an aim to strengthen the non-university sector further. In strategic terms, these reforms aimed at increasing the quality, efficiency and accessibility of higher education, as well as ensuring the contribution of higher education to the regionally-balanced development of Croatia as a knowledge society. The reform comprised regulatory policy instruments (system level legislation and procedures and criteria for accreditation), with no reliance on arguably more effective policy instruments related to the allocation of resources (funding). The reform has achieved only a small portion of its goals, establishing some non-university institutions and somewhat decreasing the number of students enrolled in professional programmes at universities. However, the reform failed to align the distinction between types of institutions and types of programmes and the binary divide thus remains blurred.

Even though discussions on policy successes and failures are necessarily normative and political, this does not mean that the conclusions reached are to be dismissed on either of those grounds. However, whether Croatia has failed or succeeded in its efforts to establish a functional binary higher education system is not as central to our discussion here, as it is to demonstrate that a policy outcome, failure or not, is always a result of a number of factors which evolve and interact.

This structural reform has continuously been embedded in more general reform efforts. This, however, may have been a double-edged sword: on the one hand, it provided impetus for the structural reform. On the other hand, in these wider reform efforts, the structural reform was actually not the most politically salient one. The main focus was on the reform of the major part of the higher education sector - the universities. This made the structural reform less prominent, affecting both its design and its implementation. The situation in which the aims of the structural reforms are continuously re-iterated and the most powerful actor in the system continuously manages to 'dilute' these aims and keep its privileged position points to the necessity of bringing this most powerful actor more fully on board with the reform ideas. Since professional programmes are also a source of revenue for universities, the policy-makers may need to consider offering alternative financial incentives as 'part of the deal'. Thus, in contexts 
characterized by high professional autonomy that allows for discretion in interpretation and enforcement of rules, such as higher education (for a more general argument see Thelen and Mahoney 2010), reliance on one type of policy instruments - regulation - may not bring about the desired policy outcomes.

As we have argued in this chapter, for any effort that aims to create change in a policy domain or for policy analysis for that matter, higher education included, one needs to approach it contextually. In other words, doing justice to a public policy assessment means taking into account, on one hand, governance arrangements, as well as the way state apparatus operates. On the other hand, it also means appreciating that the policy, together with its context, is always evolving. Ideas change or gain new dimensions while phases of the process overlap, rendering our efforts to tell policy design from policy implementation difficult, or perhaps even meaningless. Actors vary in their authority and capacity to act, sometimes resulting in a striking power asymmetry. In our case this proved crucial for the process and the outcome. Powerful actors penetrate structures and even 'hijack' them for their goals when needed. Institutions may be more resilient, but these are neither static. Formal rules, such as laws, seemed to be easier to change than non-formal ones. The authority of the state, together with its legislative, executive and judicial branches, in a policy domain that is de facto public, can also be challenged, and even successfully so, by other actors, such as the academic profession and its organisations.

As a result of this 'messiness', the policy process is, as Lindblom suggested more than half a century ago, more of a 'muddling through' (1959) than a rational and straightforward one. Therefore, we argue, policy analysis can only benefit from this appreciation. Assuming such approach in this chapter has, we contend, enabled us to offer a more comprehensive understanding of why Croatia has spent more than two decades struggling to strengthen the horizontal differentiation in its higher education. Focusing solely on policy itself would, arguably, have been a less fruitful exercise.

\section{References}

Bacevic, Jana. 2014. "(Education for) work sets you free: 'employability' and higher education in former Yugoslavia and its successor states." European Journal of Higher Education no. 4 (3):281-296. doi: 10.1080/21568235.2014.916534.

Bleiklie, Ivar, Jürgen Enders, and Benedetto Lepori. 2015. "Organizations as Penetrated Hierarchies: Environmental Pressures and Control in Professional Organizations." Organization Studies no. 36 (7):873-896. doi: 10.1177/0170840615571960.

Bovens, Mark, and Paul 't Hart. 2016. "Revisiting the study of policy failures." Journal of European Public Policy:1-14. doi: 10.1080/13501763.2015.1127273. 
Cvitan, Mirna, Karin Doolan, Thomas Farnell, and Teo Matković. 2011. Socijalna i ekonomska slika studentskog života u Hrvatskoj: Nacionalno izvješće istraživanja EUROSTUDENT za Hrvatsku. Zagreb: Institut za razvoj obrazovanja.

Doolan, Karin, Danijela Dolenec, and Mladen Domazet. 2011. Hrvatski sustav financiranja visokog obrazovanja u europskom kontekstu: komparativna studija. Zagreb: Institut za razvoj obrazovanja.

Gornitzka, Åse. 1999. "Governmental policies and organisational change in higher education." Higher education no. 38 (1):5-31.

Gornitzka, Åse, and Peter Maassen. 2000. "Hybrid steering approachs with respect to European higher education" Higher Education Policy no. 13(3): 267-285.

Kingdon, John W. 2003. Agendas, alternatives, and public policies. New York: Longman.

Lindblom, Charles E. 1959. "The science of "muddling through"." Public Administration Review no. 19 (2):79-88.

Majone, Giandomenico, and Aaron Wildavsky. 1984. "Implementation as Evolution." In Implementation: How Great Expectations in Washington Are Dashed in Oakland; Or, Why It's Amazing that Federal Programs Work at All, This Being a Saga of the Economic Development Administration as Told by Two Sympathetic Observers Who Seek to Build Morals on a Foundation of Ruined Hopes, edited by Jeffrey L. Pressman and Aaron Wildavsky, 163-180. Berkeley: University of California Press.

May, Peter J. 2015. "Implementation failures revisited: Policy regime perspectives." Public Policy and Administration no. 30 (3-4):277-299. doi: 10.1177/0952076714561505.

Musselin, Christine. 2005. "Change or Continuity in Higher Education Governance?" In Governing knowledge: A study of continuity and change in higher education, edited by Ivar Bleiklie and Mary Henkel, 65-79. Dordrecht: Springer.

Olsen, Johan P. 1988. "Administrative reform and theories of organization" In Organizing governance, governing organization, edited by Colin Campbell and Guy B. Peters, 233254. Pittsburgh: University of Pittsburgh Press.

Orosz, Anna. 2008. "The Bologna Process in Croatia." European Education no. 40 (2):66-84.

Peters, B Guy. 2015. "State failure, governance failure and policy failure: Exploring the linkages." Public Policy and Administration no. 30 (3-4):261-276. doi: 10.1177/0952076715581540.

Reichard, Max. 1992. "Politics and Culture in Croatian Higher Education: A Comparative Perspective on Educational Reform." Community services catalyst no. 22 (4).

Sørensen, Eva, and Torfing, Jacob. 2003. "Network Politics, Political Capital, and Democracy" International Journal of Public Administration no. 26(6): 609-634.

Thelen, Kathleen Ann, and James Mahoney. 2010. Explaining institutional change: ambiguity, agency, and power. Cambridge: Cambridge University Press.

Tsebelis, George. 2002. Veto players: How political institutions work. Princeton: Princeton University Press.

Zgaga, Pavel. 2013. "Higher education research and higher education policy in South-East Europe." European Journal of Higher Education:1-15. doi: 10.1080/21568235.2013.819671.

Zittoun, Philippe. 2015. "Analysing policy failure as an argumentative strategy in the policymaking process: A pragmatist perspective." Public Policy and Administration no. 30 (3-4):243-260. doi: 10.1177/0952076715581634. 


\section{Primary sources}

- 1993, Law on Higher Education Institutions from (Zakon o visokim učilištima, 96/93), and its amendments in 1994 (34/94), 1995 (21/95, 48/95), 1996 (29/96, 54/96, 59/96) and $2000(14 / 00,67 / 00,94 / 00,129 / 00)$

- 2000, Decision of the Constitutional Court of the Republic of Croatia (Odluka i rješenje Ustavnog suda Republike Hrvatske, 14/2000)

- 2001, White Paper on Croatian Education, the Government of the Republic of Croatia, Office for the Strategy of Development of the Republic of Croatia

- 2003, Law on Science and Higher Education (Zakon o znanstvenoj djelatnosti i visokom obrazovanju, 123/03) and its amendments in 2004 (105/04, 174/04), 2007 (2/07) and $2011(63 / 11)$

- 2003, Green Paper on Growth and Development (Preporuke za povećanje konkurentnosti, Obrazovanje za rast i razvoj)

- 2003, Bologna national report of Croatia, prepared for the Berlin Ministerial Summit

- 2005, Education Sector Development Plan 2005-2010 (Plan razvoja sustava odgoja i obrazovanja 2005. - 2010.)

- 2006, Decision of the Constitutional Court of the Republic of Croatia (Odluka Ustavnog suda Republike Hrvatske, 02/07)

- 2007, Bologna national report of Croatia, prepared for the London Ministerial Summit

- 2009, Law on Quality Assurance in Science and Higher Education (Zakon o osiguravanju kvalitete u znanosti i visokom obrazovanju, 45/09)

- 2011, Network of HEIs and study programmes in Croatia, developed by ASHE and NCHE and adopted by the Croatian Parliament in October 2011 (Mreža visokih učilišta i studijskih programa u Republici Hrvatskoj)

- 2013, Law on Croatian Qualifications Framework (Zakon o Hrvatskom kvalifikacijskom okviru, 22/13)

- 2014, Strategy for Education, Science and Technology adopted by the Croatian Parliament in October 2014 (Strategija obrazovanja, znanosti i tehnologije, usvojio Hrvatski Sabor u oktobru 2014.) 


\section{Interviewed experts}

- Sandra Bezjak, Deputy Director of the Agency for Science and Higher Education (ASHE)

- Slavica Ćosović Bajić, Chair of the Council polytechnics and schools of professional HE; Dean of Polytechnic of Zagreb (public non-university HEI)

- Vlatko Cvrtila, Dean of VERN (private non-university HEI based in Zagreb), former professor at the Faculty of Political Science at the University of Zagreb

- Marko Jelić, Former Dean of Polytechnic of Knin (public non-university HEI in Knin, one of the poorest regions of Croatia)

- Ana Tecilazić Goršić, Ministry of Science, Education and Sports; Head of Department for higher education quality, international cooperation and European initiatives 